\title{
Regulation of insulin-like growth factor-binding protein-3 ternary complex formation in pregnancy
}

\author{
M S Lewitt, F P Scott ${ }^{1}$, N M Clarke, T Wu, M J Sinosich ${ }^{2}$ and \\ R C Baxter ${ }^{3}$ \\ Department of Endocrinology, Royal Prince Alfred Hospital and University of Sydney, Sydney, Australia, ${ }^{1}$ Department of Obstetrics and Gynaecology, \\ Royal Prince Alfred Hospital, Sydney, Australia, ${ }^{2}$ Department of Obstetrics and Gynaecology, Royal North Shore Hospital, Sydney, Australia and \\ ${ }^{3}$ Kolling Institute of Medical Research, Royal North Shore Hospital, Sydney, Australia \\ (Requests for offprints should be addressed to M Lewitt, Department of Endocrinology, University of Sydney, Sydney, New South Wales 2006, Australia)
}

\begin{abstract}
The IGFs are believed to be important in pregnancy and are implicated in the pathophysiology of pre-eclampsia. In adults the IGFs circulate primarily with IGF-binding protein-3 (IGFBP-3) and an acid-labile glycoprotein (ALS) in a $140 \mathrm{kDa}$ complex which limits IGF bioavailability. Less than 10\% of IGFBP-3 is in lower molecular weight forms. We have investigated the developmental regulation of the IGF/IGFBP system in normal and pre-eclamptic pregnancies with particular emphasis on the IGFBP-3 ternary complex. Circulating levels of IGF-I, IGFBP-3 and ALS, and their degree of association in the ternary complex in the fetus increased with gestational age. In neonatal serum from deliveries $<35$ weeks' gestation IGFBP-3 was predominantly in $30-50 \mathrm{kDa}$ form(s)
\end{abstract}

and ALS was a limiting factor for ternary complex formation. In serum from deliveries $>35$ weeks both ALS and IGFs were limiting but approximately $25 \%$ of IGFBP-3 was unable to form the ternary complex even in the presence of excess ALS and IGF-I. Serum IGFBP-1, -2 and -6 concentrations tended to decrease with increasing gestational age. In pre-eclamptic pregnancies, amniotic fluid IGFBP-2, -3 and -6 levels decreased with gestational age while IGFBP-1 levels did not show the normal decline. We speculate that the endocrine IGF system develops in the fetus during the third trimester of pregnancy when ALS levels increase.

Journal of Endocrinology (1998) 159, 265-274

\section{Introduction}

The insulin-like growth factor (IGF) system is believed to be important in fetal growth (Daughaday \& Rotwein 1989, Wang \& Chard 1992). IGF-I and IGF-II and their receptors are widely expressed in the human fetus, suggesting that they might play important paracrine or autocrine roles (Daughaday \& Rotwein 1989). The bioavailability and activity of the IGFs is determined by their association with a family of IGF-binding proteins, the IGFBPs, which are also expressed and secreted by a wide range of human fetal tissues (Hill \& Clemmons 1992, Delhanty et al. 1993, Pannier et al. 1994, Braulke et al. 1996). Protease activity may be an important determinant of the paracrine function of the IGFBPs in the fetus (Braulke et al. 1996). The IGFs appear to have an important endocrine function in the adult. They circulate predominantly in a $140 \mathrm{kDa}$ complex with IGFBP-3 and an acid-labile glycoprotein (ALS) and also in association with IGFBP-3 and the other IGFBPs in binary complexed forms (Baxter 1994). IGF-I and IGFBP-3 concentrations in the adult circulation tend to vary in parallel, supporting the observation that association of an IGF with IGFBP-3 is required before a ternary complex with ALS can form in vitro (Baxter \& Martin 1989) or in vivo (Lewitt et al. 1993). Furthermore ALS is crucial to the stability of the IGFs and of IGFBP-3 in the circulation (Lewitt et al. 1993) and determines their circulating half lives of many hours (Guler et al. 1989). A proportion of IGFBP-3 also exists in forms of lower molecular weight in the circulation and these forms have half lives of approximately $10 \mathrm{~min}$ (Lewitt et al. 1993). It is not yet clear whether the IGFs have a significant endocrine role in the human fetus. Certainly IGF-I and IGFBP-3 also appear to be regulated in a coordinated manner, increasing with gestational age with a significant positive relationship to parameters of fetal growth (Fant et al. 1993). In contrast, circulating IGFBP-1 and IGFBP-2 levels are higher than in the adult circulation (Wang \& Chard 1992, Blum et al. 1993, Schwander \& Mary 1993, Bang et al. 1994b) and correlate inversely with IGF-I levels (Fant et al. 1993) and with birthweight (Verhaeghe et al. 1993, Giudice et al. 1995).

Concentrations of IGFs and IGFBPs are also altered in the maternal circulation compared with the non-pregnant state. There is an increase in IGFBP-3 levels measurable by RIA (Baxter \& Martin 1986). However, when samples 
are subjected to SDS-PAGE and detected by blotting with radioiodinated IGF there is an apparent reduction in IGFBP-3 (Giudice et al. 1990, Hossenlopp et al. 1990). This discrepancy is explained by the observations that, although IGFBP-3 in pregnancy serum is able to bind endogenous IGF-I and radiolabelled ALS (Suikkari \& Baxter 1992), it has a lower affinity and accelerated dissociation kinetics for iodinated IGF-I (Suikkari \& Baxter 1991, Lassarre \& Binoux 1994) due to a cationdependent protease (Liu et al. 1992, Lassarre \& Binoux 1994). The size distribution of circulating IGFs is not altered in maternal serum (Davies et al. 1991, Gargosky et al. 1991, Liu et al. 1992). Although the potential exists for altered bioavailability of IGFs the actual effect of this protease on IGF delivery to the tissues during pregnancy is not known. Compared with non-pregnant values, when measured by RIA, maternal IGFBP-1 levels increase rapidly, peak in the first trimester (Rutanen et al. 1982, Wang et al. 1991b) and have been shown to correlate inversely with birthweight (Howell et al. 1985, Hall et al. 1986). Maternal IGFBP-2 concentrations appear to decrease on ligand blotting (Giudice et al. 1990); however, the levels measured by RIA are variably reported to be low-normal (Schwander \& Mary 1993) or to increase (Chard et al. 1994).

The pre-eclampsia syndrome is a major cause of perinatal morbidity. It has been suggested that the IGF system might play a role in its pathogenesis, since there is increased mitogenic activity of unknown origin in the maternal plasma (Musci et al. 1988). Increased circulating levels of maternal IGFBP-1 have been observed in preeclampsia, although there is substantial overlap of values with control subjects at similar stages of pregnancy (Than et al. 1984, Iino et al. 1986, Howell et al. 1989). Maternal IGFBP-3 levels have variably been reported to be normal (Varma et al. 1993) or low (Wang et al. 1996).

Since the IGFBP-3 ternary complex has a fundamental role in determining IGF bioavailability, the primary aim of this study was to examine its formation in the circulation of neonates of various gestational ages. In addition, because of the uncertain role of IGFs in pre-eclampsia, we obtained samples from pre-eclamptic pregnancies. We have measured the components of the complex (IGF-I, IGF-II, IGFBP-3 and ALS) and examined the factors determining its formation. In addition we describe the levels of IGFBP-1, -2 and -6 in these neonates. The above parameters were also determined in maternal serum, neonatal arterial serum and amniotic fluid from the same pregnancies.

\section{Materials and Methods}

\section{Samples}

This study was conducted in accordance with the guidelines of the Declaration of Helsinki and with the approval of the Human Ethics Committee, Royal Prince Alfred Hospital. Samples were collected at the time of caesarean section from ten singleton pregnancies of 26-39 weeks' gestation complicated by pre-eclampsia, as defined by the Australasian Society for the Study of Hypertension in Pregnancy (Australasian Society for the Study of Hypertension in Pregnancy 1993). The degree of pre-eclampsia ranged from mild to severe. There were two control groups, one not in labour and undergoing caesarean section at 38-39 weeks' gestation $(n=11)$, and a second having spontaneous vaginal deliveries at 22-40 weeks $(n=15)$. Glucose tolerance was normal in all of the pregnancies and there were no serious maternal illnesses or evidence of fetal distress in either control group. Maternal serum, umbilical artery and vein sera, and amniotic fluid samples were obtained at the time of the caesarean section deliveries. Umbilical vein serum was obtained from the vaginal delivery group. All samples were stored at $-80{ }^{\circ} \mathrm{C}$ until analysis.

\section{Assays}

Using methods previously described, IGFBP-1 (Baxter et al. 1987), IGFBP-2 (Baxter et al. 1995), IGFBP-3 (Baxter \& Martin 1986), IGFBP-6 (Baxter \& Saunders 1992) and ALS (Baxter 1990) levels were determined by RIA. Preliminary data were reported in the proceedings of an international workshop on IGFBPs (Lewitt et al. 1995). IGF-I levels were measured by RIA after acid-ethanol extraction as previously described (Baxter et al. 1982), except that des(1-3)IGF-I (GroPep, Adelaide, Australia), iodinated using the chloramine- $\mathrm{T}$ method to a specific activity of approximately $100 \mu \mathrm{Ci} / \mu \mathrm{g}$, was used as tracer. The effective assay range was $0 \cdot 01-5 \cdot 0 \mathrm{ng}$ /assay tube. The within-assay imprecision for $20 \mu \mathrm{l}$ samples was $6.9 \%$ measured at $0.25 \mathrm{ng} /$ assay tube. IGF-II levels were measured after acid-ethanol extraction by RIA using radioiodinated des(1-6)IGF-II (GroPep) as previously described (Baxter et al. 1995). Radioiodinated des(13)IGF-I and des(1-6)IGF-II have reduced affinity for IGFBPs (Yamamoto et al. 1996).

\section{Superose-12 chromatography}

The molecular weight distribution of IGFBP-3 in serum was determined by Superose-12 gel permeation chromatography (Pharmacia, Uppsala, Sweden) in $50 \mathrm{mmol} / \mathrm{l}$ sodium phosphate, $100 \mathrm{mmol} / \mathrm{l}$ sodium chloride and $0.02 \%$ sodium azide, $\mathrm{pH} 6 \cdot 5$. The column calibration was performed as previously described (Baxter 1990). Serum (30 $\mu \mathrm{l})$ was diluted to $120 \mu \mathrm{l}$ in column buffer and $100 \mu \mathrm{l}$ were injected via a V-7 valve (Pharmacia). The column was run at $1 \mathrm{ml} / \mathrm{min}$ and $0.5 \mathrm{ml}$ fractions collected. Aliquots of $200 \mu \mathrm{l}$ (umbilical cord samples) and $25 \mu \mathrm{l}$ (maternal samples) were assayed in duplicate for IGFBP-3. Fractions 22-24 represent approximately $140 \mathrm{kDa}$ and 
Table 1 Maternal levels of IGFs and IGFBPs (ng/ml). IGF and IGFBP concentrations were measured by RIA in serum samples from 11 women not in labour undergoing caesarean section at 38-39 weeks' gestation and from 10 women undergoing caesarean section for pre-eclampsia. The pre-eclamptic group is divided into $<35$ weeks' gestation $(n=5)$ and $>35$ weeks' gestation $(n=5)$. Results are means \pm S.E.M.

\begin{tabular}{|c|c|c|c|}
\hline & $\begin{array}{l}\text { Term controls } \\
\text { (38-39 weeks) }\end{array}$ & $\begin{array}{l}\text { Pre-eclamptic } \\
\text { (<35 weeks) }\end{array}$ & $\begin{array}{l}\text { Pre-eclamptic } \\
\text { (>35 weeks) }\end{array}$ \\
\hline \multicolumn{4}{|l|}{ Peptide } \\
\hline IGF-I & $457 \pm 75$ & $235 \pm 55^{*}$ & $501 \pm 84$ \\
\hline IGF-II & $432 \pm 44$ & $396 \pm 98$ & $548 \pm 118$ \\
\hline IGFBP-1 & $317 \pm 37$ & $424 \pm 101$ & $383 \pm 134$ \\
\hline IGFBP-3 & $4670 \pm 610$ & $5120 \pm 1600$ & $7040 \pm 1100$ \\
\hline ALS & $24260 \pm 1800$ & $25970 \pm 2020$ & $35220 \pm 2980$ \\
\hline
\end{tabular}

${ }^{*} P<0 \cdot 05$, less than term control and less than pre-eclampsia $>35$ weeks' gestation.

fractions $25-27$ represent $30-50 \mathrm{kDa}$ forms of IGFBP-3. In experiments designed to determine the factors limiting formation of the IGFBP-3 ternary complex, serum samples of $30 \mu \mathrm{l}$ were incubated in vitro with and without $1 \mu \mathrm{g}$ recombinant human IGF-I (Kabi Pharmacia Peptide Hormones, Stockholm, Sweden) plus or minus $0.5 \mu \mathrm{g}$ human ALS purified from human serum (Baxter 1990) in a final volume of $120 \mu \mathrm{l}$ in column buffer. After a $30 \mathrm{~min}$ incubation at $22^{\circ} \mathrm{C}, 100 \mu \mathrm{l}$ were size fractioned by Superose-12 chromatography and $200 \mu \mathrm{l}$ aliquots assayed for IGFBP-3 by RIA.

\section{Statistics}

Results are expressed as the mean \pm S.E. Comparisons between groups were made using ANOVA and Fisher's protected least significant difference post hoc test and correlations were analysed using StatView (Abacus Concepts, Berkeley, CA, USA). The groups with samples from a range of gestational ages were also divided into groups of $<35$ weeks and $>35$ weeks. The latter group was comparable with the term caesarean controls.

\section{Results}

\section{Maternal values}

Maternal serum samples were available from the two caesarean section groups. In the pre-eclamptic women IGF-I levels were seen to increase during gestation $(r=0.583, P<0.05)$. Table 1 shows the IGF-I, IGF-II, IGFBP-1, IGFBP-3 and ALS values with the samples in the pre-eclampsia group divided into those $<35$ weeks' and those $>35$ weeks' gestation. There was no difference between the IGF-I levels in the five pre-eclamptic women $>35$ weeks' gestation and in the term caesarean controls. IGF-II, IGFBP-1, IGFBP-3 and ALS levels did not change with gestation and in the pre-eclamptic group were not significantly different from those in caesarean controls. IGFBP-2 levels varied over a wide range in the pre-eclampsia group. There were two very high values of 1103 and $1372 \mathrm{ng} / \mathrm{ml}$ in pregnancies of 27 and 31 weeks' gestation and in the other eight pre-eclamptic pregnancies the values were $278 \pm 34 \mathrm{ng} / \mathrm{ml}$, not significantly different from those in term controls $(220 \pm 59)$. No clinical parameters separated the women with the high IGFBP-2 levels from the rest of the group. IGFBP-6 levels decreased with gestation $(r=-0 \cdot 805, P<0 \cdot 001)$.

\section{Amniotic fluid values}

Samples of amniotic fluid were available from the two caesarean section groups. Table 2 shows the IGF-I, IGF-II, IGFBP-1 and IGFBP-3 values in amniotic fluid with the pre-eclampsia group divided into $<35$ weeks' and $>35$ weeks' gestation. Low concentrations of IGF-I and -II were detected in amniotic fluid. They did not vary with gestational age and the pre-eclamptic values were similar to those in controls. IGFBP-1 levels were higher in the

Table 2 Amniotic fluid levels of IGFs and IGFBPs (ng/ml). IGF and IGFBP concentrations were measured by RIA in amniotic fluid samples from 11 women not in labour undergoing caesarean section at 38-39 weeks' gestation and from 10 women undergoing caesarean section for pre-eclampsia. The pre-eclamptic group is divided into $<35$ weeks' gestation $(n=5)$ and $>35$ weeks' gestation $(n=5)$. Results are means \pm S.E.M.

\begin{tabular}{|c|c|c|c|}
\hline & $\begin{array}{l}\text { Term controls } \\
\text { (38-39 weeks) }\end{array}$ & $\begin{array}{l}\text { Pre-eclamptic } \\
\text { (<35 weeks) }\end{array}$ & $\begin{array}{l}\text { Pre-eclamptic } \\
\text { (>35 weeks) }\end{array}$ \\
\hline \multicolumn{4}{|l|}{ Peptide } \\
\hline IGF-I & $11 \cdot 1 \pm 1 \cdot 0$ & $8 \cdot 9 \pm 1 \cdot 2$ & $10 \cdot 5 \pm 1 \cdot 3$ \\
\hline IGF-II & $59 \pm 4$ & $57 \pm 8$ & $51 \pm 6$ \\
\hline IGFBP-1 & $20400 \pm 5400$ & $55500 \pm 12200^{*}$ & $106400 \pm 89300^{*}$ \\
\hline IGFBP-3 & $2860 \pm 320$ & $7210 \pm 730^{\dagger *}$ & $3770 \pm 720$ \\
\hline
\end{tabular}




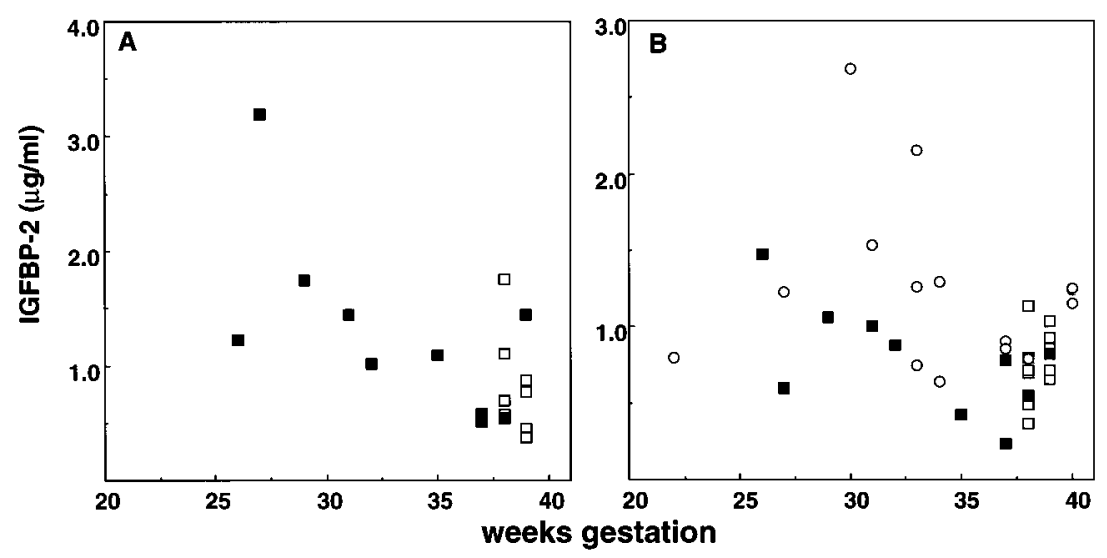

Figure 1 Relationship between gestational age and IGFBP-2 levels measured by RIA in samples from (A) amniotic fluid and (B) umbilical cord vein serum. $\square$ Caesarean section controls $(n=11) ; \bigcirc$ vaginal deliveries $(n=15) ; \quad$ pre-eclamptic pregnancies $(n=10)$.

pre-eclamptic group compared with the caesarean controls $(P<0 \cdot 05)$ and, unlike our previous observations in normal pregnancies (Baxter et al. 1987), did not vary with gestational age $(r=-0 \cdot 090)$. IGFBP-3 levels diminished with gestational age in pre-eclamptic pregnancies $(r=-0 \cdot 890, P<0 \cdot 001)$, in a similar manner to that previously reported for normal deliveries (Baxter et al. 1987). ALS was not detected in amniotic fluid. Figure 1A shows that the IGFBP-2 levels in amniotic fluid diminished with gestational age in the pre-eclamptic group $(r=-0.695$, $P<0 \cdot 005)$. In the pregnancies $>35$ weeks the amniotic fluid IGFBP-2 concentrations did not differ significantly from those in caesarean controls. IGFBP-6 levels diminished with gestational age $(r=-0 \cdot 854, P<0 \cdot 001)$. Thus, total amniotic fluid IGFBP levels greatly exceeded IGF levels and diminished during gestation.

\section{Neonatal serum values}

Neonatal serum was obtained from the two control groups and from the pregnancies complicated by pre-eclampsia. IGFBP-1 levels in neonatal serum fell with increasing gestational age $(r=-0 \cdot 434, P<0 \cdot 05)$ but were not different between pre-eclamptic deliveries and the vaginal delivery control group. In the pregnancies $<35$ weeks neonatal IGFBP-1 levels were $520 \pm 186 \mathrm{ng} / \mathrm{ml}$ and $981 \pm 730 \mathrm{ng} / \mathrm{ml}$ in the pre-eclamptic and control group respectively (not significant (NS)). In the deliveries $>35$ weeks values were $161 \pm 44 \mathrm{ng} / \mathrm{ml}$ and $278 \pm 114 \mathrm{ng} / \mathrm{ml}$ respectively (NS). The relationship between IGFBP-2 levels and gestational age is shown in Fig. 1B. There was a trend for IGFBP-2 levels to fall during gestation in the pre-eclamptic group $(r=-0 \cdot 608, P=0 \cdot 06)$. IGFBP-6 decreased with gestational age. This was statistically significant for the vaginal delivery control group $(r=-0.659$, $P<0.003)$ and did not reach statistical significance for the group with pre-eclampsia $(r=-0 \cdot 502, P=0 \cdot 14)$.
The ternary complex with IGFBP-3, ALS and IGF is of primary importance in limiting IGF availability from the circulation. IGF-I levels for the three groups are shown in Fig. 2A. The increase in IGF-I levels with gestational age was significant in the pre-eclamptic group $(r=0.706$, $P<0 \cdot 005$ ). As previously published, IGF-II levels did not vary with gestational age and were not significantly different between the three groups. IGF-II levels in the vaginal delivery group were $183 \pm 35 \mathrm{ng} / \mathrm{ml}$, and the values in the pre-eclamptic group were $122 \pm 42 \mathrm{ng} / \mathrm{ml}$. Figure 2B and $\mathrm{C}$ show the IGFBP-3 and ALS levels respectively in umbilical cord vein samples. These peptides increased with gestational age in parallel with IGF-I and did not differ significantly between samples from pregnancies complicated by pre-eclampsia (IGFBP-3, $r=0.890, P<0.001$; ALS, $r=0.839, P<0.002)$ and those from the vaginal delivery control group (IGFBP-3, $r=0 \cdot 677, P<0 \cdot 005$; ALS, $r=0 \cdot 730, P<0 \cdot 002)$.

The above parameters were measured in umbilical cord arterial samples and there was no significant difference in the values obtained compared with those of umbilical cord vein samples (data not shown).

\section{Studies of ternary complex formation}

The size distribution of IGFBP-3 in cord vein serum was determined by subjecting the samples to Superose- 12 chromatography. Figure $3 \mathrm{~A}$ shows the size distribution of IGFBP-3 in the cord serum of neonates of the caesarean control group (38-39 weeks' gestation). Fractions 22-24 represent IGFBP-3 in the $140 \mathrm{kDa}$ ternary complex and fractions $25-27$, the $\sim 50 \mathrm{kDa}$ form(s) of IGFBP-3. In this control group most of the IGFBP-3 in the circulation was present in the ternary complex. Figure $3 \mathrm{~B}$ shows the size distribution in cord serum taken at the time of caesarean section from pregnancies complicated by pre-eclampsia. In contrast to the pattern of distribution in the term controls, 

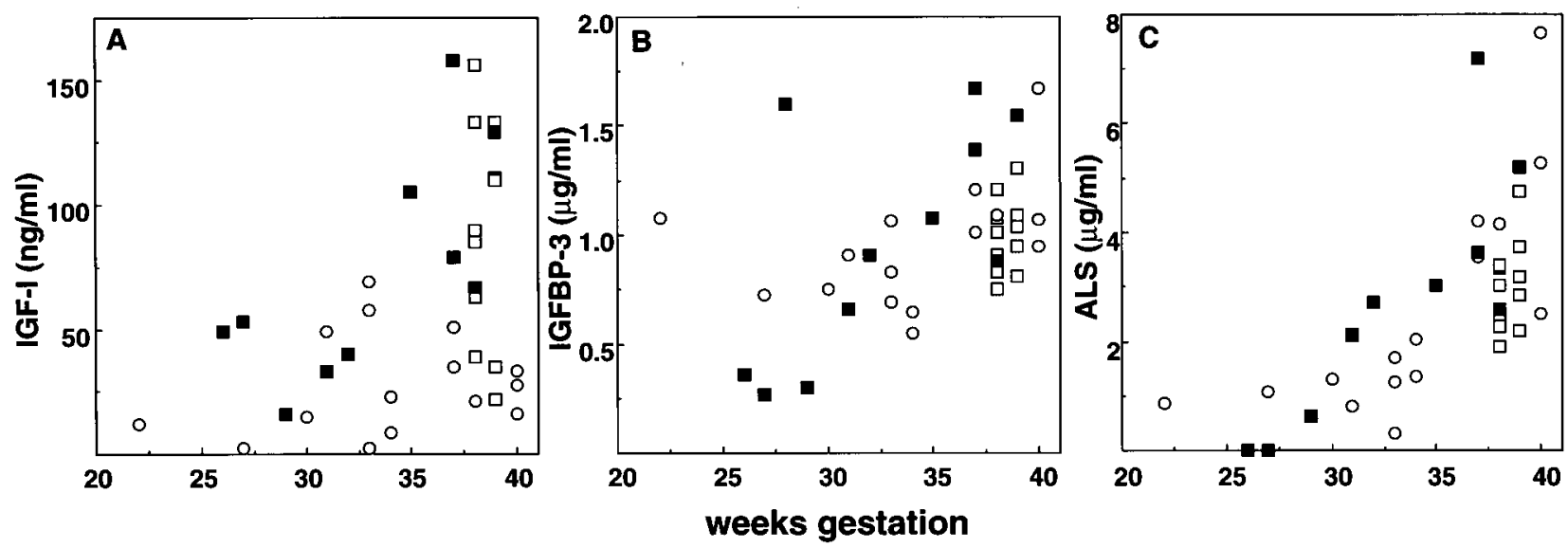

Figure 2 Relationship between gestational age and umbilical cord vein levels of components of the IGFBP-3 ternary complex. (A) IGF-I, (B) IGFBP-3, (C) ALS levels. IGFBP-3 and ALS were measured by RIA. $\square$ caesarean section controls $(n=11)$; $\bigcirc$ vaginal deliveries ( $n=15$ );

pre-eclamptic pregnancies $(n=10)$.

there was less IGFBP-3 in the ternary complex in the cord samples taken from pre-eclamptic pregnancies of $<35$ weeks' gestation so that the $140 \mathrm{kDa}$ and $50 \mathrm{kDa}$ peaks were of similar size. In the pre-eclamptic samples taken from $>35$ weeks' gestation the size distribution of IGFBP-3 was similar to that in the caesarean control group.

A similar developmental pattern of ternary complex formation was seen in the group of vaginal deliveries. Figure 4A demonstrates that in cord serum from these neonates delivered at $<35$ weeks' gestation the $140 \mathrm{kDa}$ and $50 \mathrm{kDa}$ peaks were also of similar size. In the vaginal delivery control group the IGFBP-3 molecular weight distribution pattern in neonatal samples from $>35$ weeks' gestation was similar to that in the caesarean control group and to that of pre-eclamptic deliveries of $>35$ weeks' gestation. In Fig. 4B we have expressed the degree of ternary complex formation as a ratio of IGFBP-3 in Superose-12 column fractions $22-24(140 \mathrm{kDa})$ to the IGFBP-3 in fractions $25-27(50 \mathrm{kDa})$. There was a significant correlation between the $140 \mathrm{kDa} / 50 \mathrm{kDa}$ ratio and gestational age in the cord serum from the control vaginal deliveries $(r=0 \cdot 805, P<0 \cdot 001)$ and from the preeclamptic caesarean deliveries $(r=0 \cdot 834, P<0 \cdot 001)$. These two groups did not differ significantly with respect to the degree of ternary complex formation, and at term approximately $30 \%$ of IGFBP-3 was in lower molecular weight form(s) in both groups. In contrast, when we subjected maternal serum from both the pre-eclamptic group and the caesarean controls to Superose-12 chromatography we

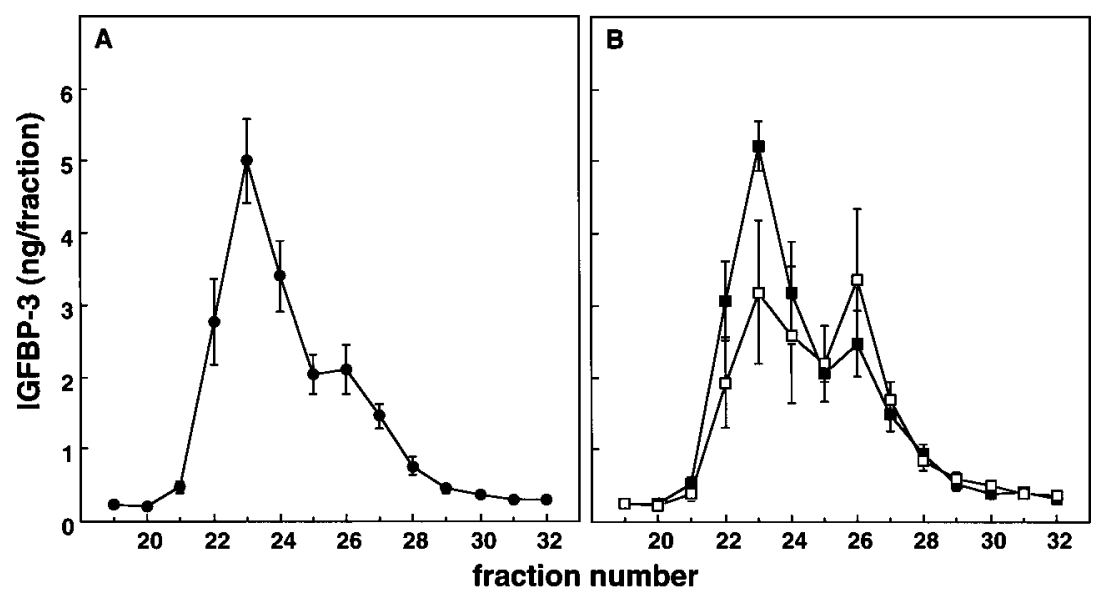

Figure 3 Molecular distribution of IGFBP-3 in umbilical cord serum taken at the time of caesarean section. Serum samples of $25 \mu$ l were size fractionated on a Superose-12 column and IGFBP-3 measured by RIA in each $500 \mu \mathrm{l}$ fraction. (A) Samples from 11 controls of 38-39 weeks' gestation. (B) Samples from pre-eclamptic pregnancies of $<35$ weeks' gestation $(\square n=5)$ and $>35$ weeks' gestation $(\boldsymbol{\square} n=5)$. Values are means \pm S.E.M. 

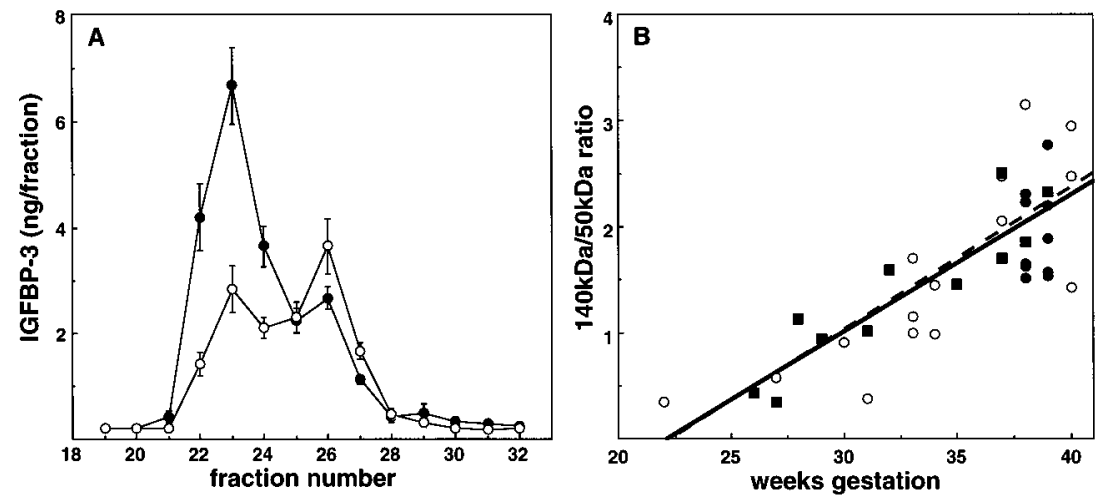

Figure 4 Molecular distribution of IGFBP-3 in umbilical cord serum from vaginal deliveries. Serum samples of $25 \mu \mathrm{l}$ were size fractionated on a Superose- 12 column and IGFBP-3 measured by RIA in each $500 \mu \mathrm{l}$ fraction. (A) Samples from neonates of $<35$ weeks' gestation $(\bigcirc n=9)$ and $>35$ weeks' gestation $(\bullet n=6)$. Values are means \pm S.E.M. (B) Ternary complex formation is presented as a ratio of IGFBP-3 in the $140 \mathrm{kDa}$ and $50 \mathrm{kDa}$ forms. Ternary complex formation correlated with gestational age in cord samples from both the pre-eclamptic caesarean deliveries (dotted line, $r=0.834, P<0.001$ ) and the vaginal deliveries without pre-eclampsia (solid line, $r=0 \cdot 805, P<0 \cdot 001$ ). $\bullet$, Caersarean section controls $(n=11)$; $\bigcirc$, vaginal deliveries $(n=15) ; \mathbf{Q}$, pre-eclamptic pregnancies $(n=10)$.

found that less than $10 \%$ of circulating IGFBP-3 was not associated in the ternary complex (data not shown), confirming previous reports (Liu et al. 1992, Suikkari \& Baxter 1992).

The size distribution of IGFBP-3 was measured in umbilical cord arterial samples and, compared with umbilical cord venous samples, there was no significant difference in the patterns observed (data not shown).

In order to determine whether IGFBP-3 in the $\sim 50 \mathrm{kDa}$ form(s) in neonatal serum was able to form a ternary complex with IGF-I and ALS we incubated serum samples with excess IGF-I plus excess ALS and compared the IGFBP-3 molecular distribution with serum in the absence of additions. In Fig. 5A we show, using serum from premature vaginal deliveries in the presence of excess IGF-I and ALS, that a proportion of IGFBP-3 in the $\sim 50 \mathrm{kDa}$ peak was able to shift to the $140 \mathrm{kDa}$ form. In term vaginal deliveries, the IGFBP-3 in the $\sim 50 \mathrm{kDa}$ form did not shift to $140 \mathrm{kDa}$ in the presence of excess IGF-I and ALS but there appeared to be a significant increase in the recovery of IGFBP-3 in the $140 \mathrm{kDa}$ form (Fig. 5B). These data are expressed as a $140 \mathrm{kDa} / 50 \mathrm{kDa}$

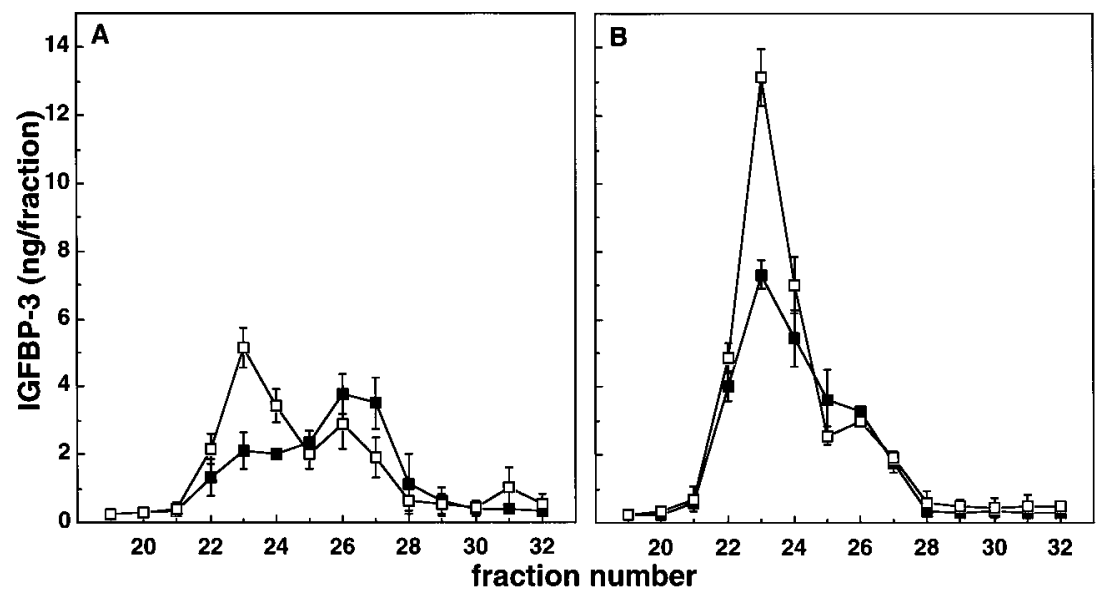

Figure 5 Molecular distribution of IGFBP-3 in umbilical cord serum in the presence and absence of excess IGF-I and ALS. Serum $(25 \mu \mathrm{l})$ was incubated at $22{ }^{\circ} \mathrm{C}$ for $2 \mathrm{~h}$ in the absence ( $\boldsymbol{\square}$ ) and presence $(\square)$ of $1 \mu \mathrm{g}$ recombinant human IGF-I and $0.5 \mu \mathrm{g}$ human ALS, and then size fractionated on a Superose-12 column and IGFBP-3 measured by RIA in each $500 \mu \mathrm{l}$ fraction. (A) Serum from three vaginal deliveries of 20-31 weeks' gestation. (B) Serum from three vaginal deliveries of 37-38 weeks' gestation. Values are means \pm S.E.M. 


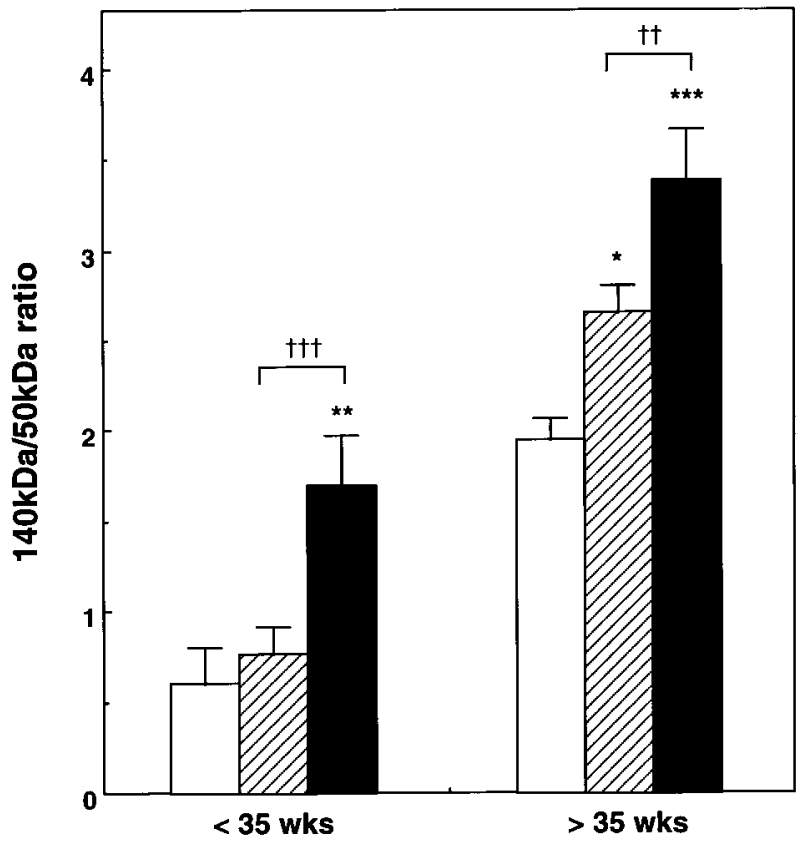

Figure 6 Effect of excess IGF-I and ALS on IGFBP-3 molecular distribution in umbilical cord serum of $<35$ weeks' and $>35$ weeks' gestation. There were three serum samples in each group. Serum $(25 \mu \mathrm{l})$ was incubated at $22{ }^{\circ} \mathrm{C}$ for $2 \mathrm{~h}$ in the presence of $1 \mu \mathrm{g}$ recombinant human IGF-I (hatched bars), $11 \mu \mathrm{g}$ IGF-I plus $0.5 \mu \mathrm{g}$ human ALS (closed bars) or no additions (open bars), and then size fractionated on a Superose- 12 column and IGFBP-3 measured by RIA in each $500 \mu \mathrm{l}$ fraction. Ternary complex formation is presented as a ratio of IGFBP-3 in the $140 \mathrm{kDa}$ and $50 \mathrm{kDa}$ forms. Values are means \pm S.E.M. Ternary complex formation was greater in cord serum from $>35$ weeks' gestation $(P<0.001$ in the presence of IGF-I, IGF-I plus ALS and no additions). ${ }^{*} P<0 \cdot 05,{ }^{* *} P<0 \cdot 01,{ }^{* * *} P<0 \cdot 001$ (compared with no additions). $+\dagger P<0 \cdot 01, \dagger_{\dagger}+P<0 \cdot 001$.

ratio in Fig. 6, where in addition we show the effect of an excess of IGF-I alone on ternary complex formation. In the premature sera, ALS and not IGF-I appeared to be a limiting factor for IGFBP-3 ternary complex formation. However, even in the presence of ALS, approximately one-third of IGFBP-3 was unable to shift to the $140 \mathrm{kDa}$ form. In the term sera both ALS and IGF-I were limiting factors for ternary complex formation of IGFBP-3. The addition of excess IGF-I alone significantly increased the $140 \mathrm{kDa} / 50 \mathrm{kDa}$ ratio $(P<0 \cdot 05)$, which increased further with the addition of excess ALS $(P<0 \cdot 01)$ so that less than $25 \%$ of IGFBP-3 was in the $\sim 50 \mathrm{kDa}$ form(s).

\section{Discussion}

In this paper we have further characterised the IGF/ IGFBP system in normal pregnancy and in pregnancies complicated by pre-eclampsia. There were two comparison groups to control for the impact of caesarean delivery and gestational age when examining the effect of preeclampsia. Our primary focus was to examine in neonates the developmental regulation of the IGFBP-3 ternary complex, since this complex is crucial to determining the bioavailability of endocrine IGFs. A clear developmental regulation of the ternary complex and its components was observed, with no difference between pre-eclamptic and control samples. IGFBP-3, ALS and IGF-I, and their association in the $\sim 140 \mathrm{kDa}$ complex, increased with gestational age during the second half of pregnancy. This increase in total IGF-I (Bennett et al. 1983, Ashton et al. 1985, Lassarre et al. 1991, Verhaeghe et al. 1993, Bang et al. 1994b) and the free form of IGF-I (Hasegawa et al. 1995) has previously been observed. IGFBP-3 is the primary circulating IGFBP in the second half of pregnancy, as it is in the adult non-pregnant circulation. The increase in IGFBP-3 with gestation has been documented previously (Bang et al. 1994b, Langford et al. 1994), although one study demonstrated no change with gestation (Giudice et al. 1995). In this study we have documented a concomitant increase in ALS levels. Bang and coworkers provided indirect evidence that ALS levels are low in fetal serum, by assessing the ability of endogenous ALS to shift exogenously added IGFBP-3 and IGF-II into the $140 \mathrm{kDa}$ form (Bang et al. 1994a).

ALS is fundamental to formation of the IGFBP-3 ternary complex and our results would suggest that ALS levels are responsible for the coordinate regulation of IGF-I and IGFBP-3 in the fetal circulation. What determines the increase in ALS during the third trimester? ALS is a growth hormone $(\mathrm{GH})$-dependent protein in the adult human circulation (Baxter 1990). However, studies in isolated rat hepatocytes suggest that there may be additional regulators of its production although no other positive regulators have been identified (Dai et al. 1994). $\mathrm{GH}$ is present and is secreted by the fetal pituitary as early as 5 weeks of gestation. However, the high GH level until 24 weeks of gestation suggests the presence of $\mathrm{GH}$ insensitivity during the first and mid trimesters (Gluckman 1995). Falling GH concentrations in the third trimester and the ALS response observed during that time in our study would indicate the development of sensitivity to $\mathrm{GH}$ actions, as a result of changes in the pathways of GH signal transduction and/or ALS synthesis, in late gestation and support a role for $\mathrm{GH}$ in late fetal growth.

In contrast to the components of the ternary complex, IGFBP-1, -2 and -6 tended to fall with increasing gestational age. Although previously published data would suggest that circulating IGFBP-1 and IGFBP-2 are elevated in fetuses with evidence of uteroplacental insufficiency (Langford et al. 1994), in our study there was no difference between the pre-eclamptic and control groups. A confounding factor in comparing these two groups is the effect of labour. If IGFBP-1 levels were elevated in relation to the stress of labour (Hills et al. 1996) to a greater 
degree than the stress of caesarean section, then any differences due to the effect of pre-eclampsia could have been masked. In addition our study group represented a range of severity of pre-eclampsia.

There was no difference in IGF and IGFBP levels between arterial and venous cord samples, supporting the concept of synthesis of endocrine IGFs (Wang et al. 1991a) and endocrine IGFBPs within the fetus. Furthermore the degree of ternary complex formation was similar in arterial and venous samples, indicating that the placental unit does not contribute to ternary complex synthesis or degradation.

Total IGF levels are very low in amniotic fluid and are exceeded by IGFBP concentrations by three orders of magnitude. In the pre-eclamptic group amniotic fluid IGFBP-1 levels did not show the decline with gestational age (Baxter et al. 1987) and it is possible that the loss of this relationship related to fetal growth retardation as has been documented in early pregnancy (Hakala-Ala-Pietilä et al. 1993). The question of whether this was of specific importance would need to be addressed with a gestational age-matched control group. Levels of IGFBP-2, -3 and -6 in amniotic fluid decreased with weeks of gestation. Taken together with previous studies of IGFBP-1 (Rutanen et al. 1982, Baxter et al. 1987, Wathen et al. 1993, Nonoshita et al. 1994), IGFBP-2 (Chard et al. 1994) and IGFBP-3 (Nonoshita et al. 1994) it is likely that in amniotic fluid IGFBPs increase to reach peak levels in the first half of pregnancy and then decline. The role of this huge excess of IGFBPs in amniotic fluid is yet to be determined.

Previous observations have suggested that a paracrine IGF system is of primary importance in early fetal growth, with widespread tissue expression of both IGF-I and IGF-II in early-mid gestation and widespread expression of IGF receptors (Daughaday \& Rotwein 1989, Wang \& Chard 1992). The IGFBPs also seem to have a paracrine role as they are ubiquitous in mid gestational tissues (Hill \& Clemmons 1992, Delhanty et al. 1993, Pannier et al. 1994, Braulke et al. 1996). The endocrine role of IGF-I in postnatal growth is generally accepted (Wang \& Chard 1992). Our observations would suggest that in the third trimester of pregnancy a circulating reservoir of IGFs is formed, supporting development of the endocrine IGF system in prenatal life. Further support for this concept is the observation that despite its relatively low concentrations, IGF-I is positively correlated with gestational age and birthweight. This endocrine system is not fully developed at birth and ALS deficiency appears to be the primary limiting factor in its formation, while in contrast in the adult ALS circulates in excess (Baxter 1990). In addition approximately one-third of IGFBP-3 in the term neonate is unable to form a ternary complex and the concentrations of the other IGFBPs are higher than in the adult circulation. The immature endocrine IGF system is thus characterised by a predominance of IGFs in binary complexes which could favour a high rate of IGF turnover and transport to the fetal tissues.

\section{References}

Ashton IK, Zapf J, Einschenk I \& MacKenzie IZ 1985 Insulin-like growth factors (IGF) 1 and 2 in human foetal plasma and relationship to gestational age and foetal size during midpregnancy. Acta Endocrinologica 110 558-563.

Australasian Society for the Study of Hypertension in Pregnancy 1993 Management of hypertension in pregnancy: executive summary. Medical Journal of Australia 158 700-702.

Bang P, Stangenberg M, Westgren M \& Rosenfeld RG 1994a Decreased ternary complex formation and predominance of a 29 kDa IGFBP-3 fragment in human fetal serum. Growth Regulation 4 68-76.

Bang P, Westgren M, Schwander J, Blum WF, Rosenfeld RG \& Stangenberg M $1994 b$ Ontogeny of insulin-like growth factorbinding protein-1, -2 , and -3 - quantitative measurements by radioimmunoassay in human fetal serum. Pediatric Research 36 $528-536$.

Baxter RC 1990 Circulating levels and molecular distribution of the acid-labile $(\alpha)$ subunit of the high molecular weight insulin-like growth factor-binding protein complex. Journal of Clinical Endocrinology and Metabolism 70 1347-1353.

Baxter RC 1994 Insulin-like growth factor binding proteins in the human circulation: a review. Hormone Research 42 140-144.

Baxter RC \& Martin JL 1986 Radioimmunoassay of growth hormone-dependent insulin like growth factor binding protein in human plasma. Journal of Clinical Investigation 78 1504-1512.

Baxter RC \& Martin JL 1989 Structure of the Mr 140000 growth hormone-dependent insulin-like growth factor binding protein complex: determination by reconstitution and affinity labeling. Proceedings of the National Academy of Sciences of the USA $\mathbf{8 6}$ 6898-6902.

Baxter RC \& Saunders H 1992 Radioimmunoassay of insulin-like growth factor binding protein-6 in human serum and other body fluids. Journal of Endocrinology 134 133-139.

Baxter RC, Brown AS \& Turtle JR 1982 Radioimmunoassay for somatomedin C: comparison with radioreceptor assay in patients with growth-hormone disorders, hypothyroidism, and renal failure. Clinical Chemistry 28 488-495.

Baxter RC, Martin JL \& Wood MH 1987 Two immunoreactive binding proteins for insulin-like growth factors in human amniotic fluid: relationship to fetal maturity. Journal of Clinical Endocrinology and Metabolism 65 423-431.

Baxter RC, Holman SR, Corbould A, Stranks S, Ho PJ \& Braund W 1995 Regulation of the insulin-like growth factors and their binding proteins by glucocorticoid and growth hormone in nonislet cell tumor hypoglycemia. Journal of Clinical Endocrinology and Metabolism 80 2700-2708.

Bennett R, Wilson DM, Liu F, Nagashima R, Rosenfeld RG \& Hintz RL 1983 Levels of insulin-like growth factors I and II in human cord blood. Journal of Clinical Endocrinology and Metabolism 57 609-612.

Blum WF, Horn N, Kratzsch J, Jorgensen JOL, Juul A, Teale D, Mohnike K \& Ranke MB 1993 Clinical studies of IGFBP-2 by radioimmunoassay. Growth Regulation 3 100-104.

Braulke T, Gotz W \& Claussen M 1996 Immunohistochemical localization of insulin-like growth factor binding protein-1, -3 and -4 in human fetal tissues and their analysis in media from fetal tissue explants Growth Regulation 6 55-65.

Chard T, Blum WF, Brunjes J, Campbell DJ \& Wathen NC 1994 Levels of insulin-like growth factor-binding protein-2 and insulin-like growth factor-II in maternal serum, amniotic fluid and extraembryonic coelomic fluid at 9-20 weeks of pregnancy. Journal of Endocrinology 142 379-383. 
Dai J, Scott CD \& Baxter RC 1994 Regulation of the acid-labile subunit of the insulin-like growth factor complex in cultured rat hepatocytes. Endocrinology 135 1066-1072.

Daughaday WH \& Rotwein P 1989 Insulin-like growth factors I and II. Peptide, messenger ribonucleic acid and gene structures, serum, and tissue concentrations. Endocrine Reviews 10 68-91.

Davies SC, Holly JMP, Coulson VJ, Cotterill AM, Abdulla AF, Whittaker PG, Chard T \& Wass JAH 1991 The presence of cation-dependent proteases for insulin-like growth factor binding proteins does not alter the size distribution of insulin-like growth factors in pregnancy. Clinical Endocrinology 34 501-506.

Delhanty PJD, Hill DJ, Shimasaki S \& Han VKM 1993 Insulin-like growth factor binding protein-4, -5 and -6 messenger RNAs in the human fetus: localization to sites of growth and differentiation. Growth Regulation 3 8-11.

Fant M, Salafia C, Baxter RC, Schwander J, Vogel C, Pezzullo J \& Moya F 1993 Circulating levels of IGFs and IGF binding proteins in human cord serum: relationships to intrauterine growth. Regulatory Peptides 48 29-39.

Gargosky SE, Owens PC, Walton PE, Owens JA, Robinson JS, Wallace JC \& Ballard FJ 1991 Most of the circulating insulin-like growth factors-I and -II are present in the $150 \mathrm{kDa}$ complex during human pregnancy. Journal of Endocrinology 131 491-497.

Giudice LC, Farrell EM, Pham H, Lamson G \& Rosenfeld RG 1990 Insulin-like growth factor binding proteins in maternal serum throughout gestation and in the puerperium: effects of a pregnancy-associated serum protease activity. Journal of Clinical Endocrinology and Metabolism 71 806-816.

Giudice LC, Dezegher F, Gargosky SE, Dsupin BA, Delasfuentes L, Crystal RA, Hintz RL \& Rosenfeld RG 1995 Insulin-like growth factors and their binding proteins in the term and preterm human fetus and neonate with normal and extremes of intrauterine growth. Journal of Clinical Endocrinology and Metabolism 80 1548-1555.

Gluckman PD 1995 The endocrine regulation of fetal growth in late gestation: the role of insulin-like growth factors. Journal of Clinical Endocrinology and Metabolism 80 1047-1050.

Guler H-P, Zapf J, Schmid C \& Froesch ER 1989 Insulin-like growth factors I and II in healthy man. Estimations of half lives and production rates. Acta Endocrinologica 121 753-758.

Hakala-Ala-Pietilä TH, Koistinen RA, Salonen RK \& Seppälä MT 1993 Elevated second-trimester amniotic fluid concentration of insulin-like growth factor binding protein-1 in fetal growth retardation. American Journal of Obstetrics and Gynecology 169 35-39.

Hall K, Hansson U, Lundin G, Luthman M, Persson B, Póvoa G, Stangenberg M \& Öfverholm U 1986 Serum levels of somatomedins and somatomedin-binding protein in pregnant women with type I or gestational diabetes and their infants. Journal of Clinical Endocrinology and Metabolism 63 1300-1306.

Hasegawa T, Hasegawa Y, Takada M \& Tsuchiya Y 1995 The free form of insulin-like growth factor I increases in circulation during normal human pregnancy. Journal of Clinical Endocrinology and Metabolism 80 3284-3286.

Hill DJ \& Clemmons DR 1992 Similar distribution of insulin-like growth factor binding proteins-1, -2 and -3 in fetal tissues. Growth Factors 6 315-326.

Hills FA, English J \& Chard T 1996 Circulating levels of IGF-I and IGF-binding protein-1 throughout pregnancy: relation to birthweight and maternal weight. Journal of Endocrinology 148 303-309.

Hossenlopp P, Segovia B, Lassarre C, Roghani M, Bredon M \& Binoux M 1990 Evidence of enzymatic degradation of insulin-like growth factor-binding proteins in the $150 \mathrm{~K}$ complex during pregnancy. Journal of Clinical Endocrinology and Metabolism 71 797-805.

Howell RJS, Perry LA, Choglay NS, Bohn H \& Chard T 1985 Placental protein 12 (PP12): a new test for the prediction of the small-for-gestational-age infant. British Journal of Obstetrics and Gynecology 92 1141-1144.
Howell RJS, Economides D, Teisner B, Farkas AG \& Chard T 1989 Placental protein 12 and 14 in pre-eclampsia. Acta Obstetrica et Gynecologica Scandinavica 68 237-240.

Iino K, Sjöberg J \& Seppälä M 1986 Elevated circulating levels of a decidual protein, placental protein 12 , in preeclampsia. Obstetrics and Gynecology 68 58-60.

Langford K, Blum W, Nicolaides K, Jones J, McGregor A \& Miell J 1994 The pathophysiology of the insulin-like growth factor axis in fetal growth failure - a basis for programming by undernutrition. European Journal of Clinical Investigation 24 851-856.

Lassarre C \& Binoux M 1994 Insulin-like growth factor binding protein-3 is functionally altered in pregnancy plasma. Endocrinology 134 1254-1262.

Lassarre C, Hardouin S, Daffos F, Forestier F, Frankenne F \& Binoux M 1991 Serum insulin-like growth factors and insulin-like growth factor binding proteins in the human fetus. Relationships with growth in normal subjects and in subjects with intrauterine growth retardation. Pediatric Research 29 219-225.

Lewitt MS, Saunders H \& Baxter RC 1993 Bioavailability of insulinlike growth factors (IGFs) in rats determined by the molecular distribution of human IGF-binding protein-3. Endocrinology 133 1797-1802.

Lewitt MS, Scott FP, Clarke NM \& Baxter RC 1995 Developmental regulation of circulating IGFBPs in preeclampsia. Progress in Growth Factor Research 6 475-480.

Liu F, Baxter RC \& Hintz RL 1992 Characterization of the high molecular weight insulin-like growth factor complex in term pregnancy serum. Journal of Clinical Endocrinology and Metabolism 75 $1261-1267$.

Musci TJ, Roberts JM, Rodgers RM \& Taylor RN 1988 Mitogenic activity is increased in the sera of preeclamptic women before delivery. American Journal of Obstetrics and Gynecology 159 1446-1451.

Nonoshita LD, Wathen NC, Dsupin BA, Chard T \& Giudice LC 1994 Insulin-like growth factors (IGFs), IGF-binding proteins (IGFBPs), and proteolyzed IGFBP-3 in embryonic cavities in early human pregnancy: their potential relevance to maternal-embryonic and fetal interactions. Journal of Clinical Endocrinology and Metabolism 79 1249-1255.

Pannier EP, Irwin JC \& Giudice LC 1994 Insulin-like growth factor binding proteins (IGFBPs) in the human fetus: tissue-specific protein secretion, immunologic characterization, and gene expression. American Journal of Obstetrics and Gynecology 171 746-752.

Rutanen E-M, Bohn H \& Seppälä M 1982 Radioimmunoassay of placental protein 12: levels in amniotic fluid, cord blood, and serum of healthy adults, pregnant women, and patients with trophoblastic disease. American Journal of Obstetrics and Gynecology 144 460-463.

Schwander J \& Mary J-L 1993 The RIA for IGFBP-2 in man: a meagre catch. Growth Regulation 3 104-108.

Suikkari A-M \& Baxter RC 1991 Insulin-like growth factor (IGF) binding protein-3 in pregnancy serum binds native IGF-I but not iodo-IGF-I. Journal of Clinical Endocrinology and Metabolism $\mathbf{7 3}$ 1377-1379.

Suikkari A-M \& Baxter RC 1992 Insulin-like growth factor-binding protein-3 is functionally normal in pregnancy serum. Journal of Clinical Endocrinology and Metabolism 74 177-183.

Than GN, Csaba IF, Szabo DG, Arany AA, Bognar ZJ \& Bohn H 1984 Serum levels of placenta-specific tissue protein 12 (PP12) in pregnancies complicated by pre-eclampsia diabetes or twins. Archives of Endocrinology 236 41-45.

Varma M, Degroot CJM, Lanyi S \& Taylor RN 1993 Evaluation of plasma insulin-like growth factor binding protein-3 as a potential predictor of preeclampsia. American Journal of Obstetrics and Gynecology 169 995-999.

Verhaeghe J, Van Bree R, Van Herck E, Laureys J, Bouillon R \& Van Assche FA 1993 C-peptide, insulin-like growth factor-I and 
factor-II, and insulin-like growth factor binding protein-1 in umbilical cord serum: correlations with birth weight. American Journal of Obstetrics and Gynecology 169 89-97.

Wang HS \& Chard T 1992 The role of insulin-like growth factor-I and insulin-like growth factor-binding protein-1 in the control of human fetal growth. Journal of Endocrinology 132 11-19.

Wang HS, Lim J, English J, Irvine L \& Chard T 1991a The concentration of insulin-like growth factor-I and insulin-like growth factor-binding protein-1 in human umbilical cord serum at delivery: relation to fetal weight. Journal of Endocrinology 29 459-464.

Wang HS, Perry LA, Kanisius J, Iles RK, Holly JMP \& Chard T $1991 b$ Purification and assay of insulin-like growth factor-binding protein-1: measurement of circulating levels throughout pregnancy. Journal of Endocrinology 128 161-168.

Wang HS, Lee JD, Cheng BJ \& Soong YK 1996 Insulin-like growth factor-binding protein 1 and insulin-like growth factor-binding protein 3 in pre-eclampsia. British Journal of Obstetrics and Gynaecology 103 654-659.

Wathen NC, Egembah S, Campbell DJ, Farkas A \& Chard T 1993 Levels of insulin-like growth factor-binding protein-I increase rapidly in amniotic fluid from 11 to 16 weeks of pregnancy. Journal of Endocrinology 137 R1-R4.

Yamamoto H, Murphy LJ \& Kato Y 1996 Disposition of radiolabelled insulin-like growth factor I (IGF-I), IGF-II and their N-terminal truncated variants in rats. Endocrine Journal $43 \mathrm{~S} 77-\mathrm{S} 80$.

Received 11 September 1997

Revised manuscript received 15 June 1998

Accepted 30 June 1998 